Pak. j. sci. ind. res. Ser. A: phys. sci. 201559 (1) 60-62

\title{
Short Communication \\ Activated Sludge Process and its Suitability for Treatment of Tannery Waste Water
}

\author{
Niaz Ahmed Memon ${ }^{a *}$, Nisar Ahmed ${ }^{b}$, Nusrat Jalbania, Tahira Ayaz ${ }^{b}$, Razia Bagum ${ }^{a}$ \\ and Alia Bano Munshi ${ }^{\mathrm{a}}$ \\ ${ }^{a}$ PCSIR Laboratories Complex, Shahrah-e-Dr. Salimuzzaman Siddiqui, Karachi-75280, Pakistan \\ ${ }^{b}$ Leather Research Centre, PCSIR, D-102, S.I.T.E., South Avenue, Karachi-75700, Pakistan \\ (receivd April 30, 2014; revised January 1, 2015; accepted January 14, 2015)
}

\begin{abstract}
This study was conducted for the treatment of tannery wastewater and to develop simple design criteria under local conditions. $\mathrm{BOD}_{5}, \mathrm{COD}$, total $\mathrm{Cr}, \mathrm{SO}_{4}{ }^{2-}, \mathrm{S}^{2-}, \mathrm{SS}$, TDS and TS of the influent and effluent were measured to find process efficiency at various mixed liquor volatile suspended solids (MLVSS), dissolved oxygen (DO) and hydraulic detention time. Results of the study demonstrated that an efficiency of above parameters $93.0 \%, 92.5 \%, 94.9 \%, 62.6 \%, 98.2 \%, 87.9 \%, 82.1 \%$ and $82.4 \%$, respectively, could be obtained if the activated sludge process (ASP) is operated at the MLVSS concentration of 3500-4500 mg/L, (DO) concentration of 4.1-5.5 mg/L keeping an aeration time of $12 \mathrm{~h}$.
\end{abstract}

Keywords: activated sludge, biological treatment, tannery wastewater

Treatment of tannery effluent through the use of activated sludge process has been reported by many researchers (Ahmed et al., 2014; Al-Hussieny et al., 2014; Deepika et al., 2014; Pal et al., 2014; Shyam et al., 2014; Ambreen et al., 2013; Mouna et al., 2013; Niaz et al., 2012; Durai et al., 2011). All these studies indicate a BOD removal of $90-97 \%$ and COD $60-80 \%$ when combined with physicochemical pretreatment for the tannery effluent. The characteristics of tannery effluent vary considerably from tannery to tannery (Ilou et al., 2014). A survey was conducted in Pakistan for quality characteristics range of effluent from tanneries processing as given in Table 1 (Iqbal et al., 1998). Various parameters of importance relating to growth of microorganisms and substrate utilization on which the operation of the reactor is based has been studied by Bestawy et al. (2014); Khairnar et al. (2014) and Marco et al. (2014).

The present work was carried out that activated sludge process (ASP) for the treatment of settled tannery effluent and to develop general guidelines for the process design under local conditions. A bench scale continuous flow activated sludge reactor was used in this study. It consisted of an aeration tank of $300 \mathrm{~L}$ capacity and a settling portion of $200 \mathrm{~L}$ capacity.

The influent was subjected to settling in an underground tank. A peristaltic pump used to fill the settled influent to the aeration tank and pure oxygen cylinder was used

*Author for correspondence; E-mail: niazmemon2000@yahoo.com to inject the oxygen to the aeration tank; a portion of gas was wasted from the tank to reduce the concentration of carbon dioxide. Pure oxygen was supplied by a fine bubble diffuser; flow was regulated at $4 \mathrm{mg} / \mathrm{L} / \mathrm{min}$ by a flow meter. The reactor had to operate at different MLVSS and DO concentrations. Due to unavailability of mechanical return sludge facility, $100 \%$ of the settled sludge was daily removed from the final clarifier tank and manually returned to the aeration tank. In order to maintain the desired MLVSS and DO concentration in the reactor the calculated fraction of the volume of the aeration tank (ranging from one third to one tenth) was removed manually on daily basis and the tank was filled to the original volume by the treated effluent. No external nutrients were added to the influent (Vaiano et al., 2014; Pradyut et al., 2013).

Pure oxygen was supplied through diffuser stones to maintain a DO level of more than $3 \mathrm{mg} / \mathrm{L}$. Temperature and $\mathrm{pH}$ values for settled influent and effluent were measured on daily basis while, MLVSS in the reactor, COD, BOD, total $\mathrm{Cr}, \mathrm{SO}_{4}{ }^{2-}, \mathrm{S}^{2-}, \mathrm{SS}$, TDS and TS of influent and effluent were measured twice a week.

The three chosen operating parameters i.e. MLVSS concentration, detention time (è) and DO were varied during the course of the study keeping into consideration the generally applied range in activated sludge process for industrial effluent treatment (Pooja, 2014; Zahrim et al., 2009). The reactor was operated for an MLVSS concentration range of 1500-4500 mg/L, DO concentration $1.9-5.5 \mathrm{mg} / \mathrm{L}$ and è value of $4-12 \mathrm{~h}$, respectively. 
During the course of study, $\mathrm{pH}$ of the reactor was varied between 7.8 and 8.23 which is a suitable range for biological treatment. DO of the reactor was maintained above $4 \mathrm{mg} / \mathrm{L}$ which is required for satisfactory biological treatment. A large amount of sludge is generated along with high energy consumption in the process (Table 1).

Table 1. Range of tannery effluent quality parameters

\begin{tabular}{|c|c|}
\hline Parameters & Range \\
\hline pH (unsettled effluent) & $7.3-10$ \\
\hline $\mathrm{BOD}_{5}, \mathrm{mg} / \mathrm{L}$ (30 min settling) & $840-18,620$ \\
\hline $\mathrm{COD}, \mathrm{mg} / \mathrm{L}$ (30 min settling) & $1320-54,000$ \\
\hline Suspended solids, mg/L (30 min settling) & $220-1610$ \\
\hline Settleable solids, mg/L (30 min settling) & $11-40$ \\
\hline Sulphate, $\mathrm{mg} / \mathrm{L}$ (unsettled effluent) & $800-6480$ \\
\hline Sulphide, $\mathrm{mg} / \mathrm{L}$ (at 0 time settling) & $800-6480$ \\
\hline Chromium, mg/L (unsettled effluent) & $41-133$ \\
\hline
\end{tabular}

Experimental work was performed for a period of 190 days. The treatment efficiency of the reactor in terms of BOD, COD, total $\mathrm{Cr}, \mathrm{SO}_{4}{ }^{2-}, \mathrm{S}^{2-}, \mathrm{SS}$, TDS and TS removals was studied for MLVSS concentrations of $1500,2000,2500,3000,3500$ and $4500 \mathrm{mg} / \mathrm{L}$, DO 1.9, $1.8,3.2,3.1,4.1$ and $4.3 \mathrm{mg} / \mathrm{L}$ and retention time 2,4 , 6,8 and $12 \mathrm{~h}$. It was noted that the process efficiency improved with increase in MLVSS, DO concentrations and è. Under optimum conditions thus the results are showed, ASP should be operated at MLVSS concentration of 3500-4500 mg/L, DO concentration $4.5 \mathrm{mg} / \mathrm{L}$ and è value of $12 \mathrm{~h}$. It is thus proposed to carry out bench scale studies for obtaining optimal values of the above said parameters for a specific tannery before designing a biological treatment system.

As shown in Fig. 1, maximum removal efficiency of $93.0 \%, 92.5 \%, 94.9 \%, 62.6 \%, 98.2 \%, 87.5 \%, 82.1 \%$ and $82.4 \%$ was achieved at MLVSS concentration of $3500-4500 \mathrm{mg} / \mathrm{L}$ and è of $12 \mathrm{~h}$ for $\mathrm{BOD}_{5}, \mathrm{COD}$, total $\mathrm{Cr}, \mathrm{SO}_{4}{ }^{2-}, \mathrm{S}^{2-}, \mathrm{SS}$, TDS and TS, respectively, as summarized in Table 2. Furthermore, residual values of $\mathrm{BOD}_{5}$ and COD at this MLVSS and è are $65 \mathrm{mg} / \mathrm{L}$ and $140 \mathrm{mg} / \mathrm{L}$, respectively. It shows that $\mathrm{BOD}_{5}$ and COD meet National Environmental Quality Standards (NEQS) limits, which are 80 and $150 \mathrm{mg} / \mathrm{L}$. As indicated in Table 3, an average $\mathrm{COD} / \mathrm{BOD}_{5}$ ratio of 1.93 and 2.01, respectively. In the light of these results, it was concluded that a reasonably good approximation of $\mathrm{BOD}_{5}$ can be obtained from a COD measurement once a relationship has been established between the two parameters from the available data.

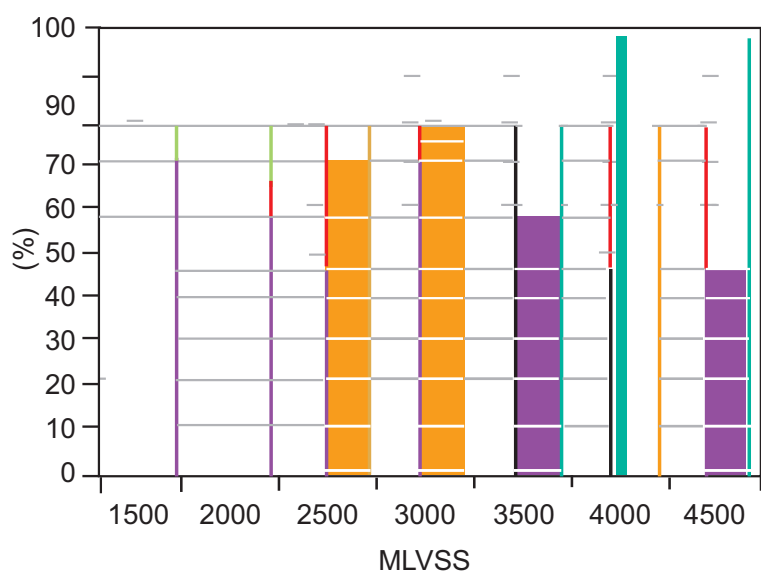

BOD, COD, Chrome, $\square$ Sulphate, Sulphide, SS, TDS, TS,

Fig. 1. Removal of pollutants.

Table 2. Removal efficiency at 3500-4500 MLVSS $\mathrm{mg} / \mathrm{L}, 12 \mathrm{~h}$ time, $5.5 \mathrm{mg} / \mathrm{L}$ DO and $\mathrm{pH} 7.93$

\begin{tabular}{llll}
\hline \hline Parameters & $\begin{array}{l}\text { Mean } \\
\text { influent }\end{array}$ & $\begin{array}{l}\text { Mean } \\
\text { effluent }\end{array}$ & $\begin{array}{l}\text { Removal } \\
\text { efficiency (\%) }\end{array}$ \\
\hline BOD $_{5}(\mathrm{mg} / \mathrm{L})$ & 982 & 69 & 93.0 \\
COD $(\mathrm{mg} / \mathrm{L})$ & 1876 & 140 & 92.5 \\
Total chrome (mg/L) & 917 & 47 & 94.9 \\
Sulphate (mg/L) & 5378 & 2010 & 62.6 \\
Sulphide (mg/L) & 285 & 05 & 98.2 \\
SS (mg/L) & 1260 & 152 & 87.9 \\
TDS (mg/L) & 8536 & 1530 & 82.1 \\
TS (mg/L) & 9517 & 1668 & 82.4 \\
\hline \hline
\end{tabular}

Table 3. Influent and effluent $\mathrm{COD}$ and $\mathrm{BOD}_{5}$ ratio

\begin{tabular}{|c|c|c|c|c|}
\hline \multicolumn{2}{|c|}{$\begin{array}{l}\text { Average COD } \\
(\mathrm{mg} / \mathrm{L})\end{array}$} & \multicolumn{2}{|c|}{$\begin{array}{l}\text { Average } \mathrm{BOD}_{5} \\
(\mathrm{mg} / \mathrm{L})\end{array}$} & \multirow[t]{2}{*}{$\begin{array}{l}\text { Average } \\
\mathrm{COD} / \mathrm{BOD}_{5}\end{array}$} \\
\hline Range & Mean & Range & Mean & \\
\hline \multicolumn{4}{|c|}{ Influent } & \\
\hline $1700-2023$ & 1861 & $901-1025$ & 963 & 1.93 \\
\hline \multicolumn{4}{|c|}{ Effluent } & \\
\hline $140-1018$ & 579 & $511-65$ & 288 & 2.01 \\
\hline
\end{tabular}

ASP is a feasible treatment technology for tannery wastewater especially where limited space restricts the use of other biological methods. ASP for Leather Research Centre may be operated with MLVSS concentration of $3500-4500 \mathrm{mg} / \mathrm{L}$, DO concentration of $4.1-4.3 \mathrm{mg} / \mathrm{L}$ and è value of $10-12 \mathrm{~h}$ in order to obtain optimal removal 
efficiencies with respect to $\mathrm{BOD}_{5}, \mathrm{COD}$, total $\mathrm{Cr}, \mathrm{SO}_{4}{ }^{2-}$, $\mathrm{S}^{2-}$, SS, TDS and TS. However, for a specific tannery, bench scale studies to find out the optimal values of these parameters are needed prior to the design of biological unit. The effluent meets NEQS for $\mathrm{BOD}_{5}, \mathrm{COD}, \mathrm{S}^{2-}$ and SS at the above stated MLVSS, DO concentration and è value (Fig. 1). However, total $\mathrm{Cr}, \mathrm{SO}_{4}{ }^{2-}$, TDS and TS limit for NEQS could not be qualified. In addition, it must be required with physicochemical pretreatment for the tannery effluent and it is suggested that Pakistan Environmental Protection Agency may consider modifying the NEQS limits. In addition, effect of different MLVSS, DO concentration and detention time on the efficiency of settling tank may be investigated.

\section{References}

Ahmed, M., Abou, E., Mahmoud, M.S. 2014. Tannery wastewater treatment using activated sludge process system (Lab scale modeling). International Journal of Engineering and Technical Research (IJETR), 2: 21-28.

Al-Hussieny, A.A., Lamyia, A., Thijar, A.F., Elaf, S.M. 2014. Study of sludge and comparison for various wastewater treatment. International Journal of Advanced Research, 2: 292-304.

Ambreen, L., Muhammad, N.C., Shazia, I. 2013. Biological treatment of dairy wastewater using activated sludge. Science Asia, 39: 179-185.

Bestawy, E., Al-Hejin, A., Amer, R., Kashmeri, R.A. 2014. Decontamination of domestic wastewater using suspended individual and mixed bacteria in batch system. Journal of Bioremediation Biodegradation, 5: 231.

Deepika, J., Gengadevi, R., Saravanan, K. 2014. Effluent treatment of tannery industries: Optimization of experimental data using RSM. Journal of Chemical Engineering and Research, 2: 1-9.

Durai, G., Rajasimman, M. 2011. Biological treatment of tannery wastewater, A review. Journal of Environmental Science and Technology, 4: 1-17.

Ilou, I., Souabi, S., Digua, K. 2014. Quantification of pollution discharges from tannery wastewater and pollution reduction by pre-treatment station. International Journal of Science and Research (IJSR), 3: 1706-1715.

Iqbal, M., Haque, I., Berns, J.A.S. 1998. The Leather Sector, Environmental Report, Environmental Technology Programme for Industry (ETPI), Federation of Pakistan Chambers of Commerce and Industry, (FPCCI), Federation House, Karachi, Pakistan.

Khairnar, K., Pal, P., Chandekar, R.H., Paunikar, W.N. 2014. Isolation and characterization of bacteriophages infecting nocardioforms in wastewater treatment plant. Biotechnology Research International, DOI:10.1155/2014/151952.

Marco, S., Javier, M., Ochando, P., Luca, D.P. 2014. On the relationship between suspended solids of different size, the observed boundary flux and rejection values for membranes treating a civil wastewater stream. Membranes, 4: 414-423.

Mouna, F., Mohammed, M., Mohamed, B. 2013. Contribution to optimize the biological treatment of synthetic tannery effluent by the sequencing batch reactor. Journal of Materials and Environmental Science, 4: 532-541.

Niaz, A., Saeed, M., Ayaz, T., Khan, M.A. 2012. Removal of pollutants from the liming effluent in course of leather processing. Pakistan Journal of Scientific and Industrial Research, 55: 155-162.

Pal, P., Khairnar, K., Paunikar, W.N. 2014. Causes and remedies for filamentous foaming in activated sludge treatment plant. Global NEST Journal, 16: 762-772.

Pooja, R.N. 2014. Removal of organic matter from wastewater by activated sludge process - Review. International Journal of Science, Engineering and Technology Research, 3: 1260-1263.

Pradyut, K., Anupam, D., Somnath, M. 2013. Treatment of slaughter house wastewater in a sequencing batch reactor: Performance evaluation and biodegradation kinetics. BioMed Research International, DOI: 10.1155/2013/134872.

Shyam, K., Pradyumna, S., Sapkal, V.S., Sapkal, R.S. 2014. Performance enhancement of recirculated membrane bioreactor (RMBR) with dual effect of cross flow velocity and operating temperature for wastewater treatment. International Journal of Emerging Technology and Advanced Engineering, 4: 134-140.

Vaiano, V., Sannino, D., Caracciolo, D., Naviglio, B., Calvanese, G., Ciambelli, P. 2014. Catalytic combustion of tannery sludge in a rotating reactor. Journal of Advanced Chemical Engineering, 4: 1-5.

Zahrim, A.Y., Rachel, F.M., Menaka, S., Su, S.Y., Melvin, F., Chan, E.S. 2009. Decolourisation of anaerobic palm oil mill effluent via activated sludge granular activated carbon. World Applied Sciences Journal, 5: 126-129. 